\title{
Learner Autonomy through Role Plays in English Language Teaching
}

\author{
Tatiana Baranovskaya \\ National Research University Higher School of Economics
}

Correspondence concerning this article should be addressed to Tatiana Baranovskaya, National Research University Higher School of Economics, Malaya Pionerskaya, 12, Moscow, Russian Federation, 115054. E-mail: tbaranovskaya@hse.ru

Valentina Shaforostova

National Research University Higher School of Economics

\begin{abstract}
Correspondence concerning this article should be addressed to Valentina Shaforostova, National Research University Higher School of Economics, Malaya Pionerskaya, 12, Moscow, Russian Federation, 115054.

E-mail: shafo@hse.ru
\end{abstract}

\begin{abstract}
Nowadays, learner autonomy is considered to be a multidimensional and diversified concept. A number of scientists have found support for the importance of learner autonomy but there is little empirical research on using different strategies for promoting and evaluating students' autonomy. Accordingly, in order to become better language learners, students should plan, implement, and evaluate their own learning. This study aims at fostering and evaluating students' autonomy by scaffolding their speaking practices through role plays in an English for Special Purposes (ESP) course. The research suggests that role-play strategies should help students develop their autonomy in acquiring ESP speaking skills. The study argues that developing autonomy is an efficient way to improve students' performance in ESP speaking skills as it provides them with relevant scaffolding. This article provides theoretical grounding for autonomy. The entry-level and post-study speaking scores (IELTS test) are compared across experimental and control groups. A class-based training course of ESP speaking was offered in an institutional setting to 38 ( 15 male, 23 female) second-year students at a national research university in Russia. A special questionnaire was developed to assess learner autonomy in ESP speaking, which proved that role play promoted learner autonomy and encouraged students to master ESP speaking skills. The results of the study indicate that students who were developing their speaking skills via role play performed significantly better than their peers in the control group. The level of their English language competence improved. The role plays in the ESP speaking course proved to be a viable and productive teaching strategy for fostering autonomy among students.
\end{abstract}

Keywords: learner autonomy, promotion of students' autonomy, role play, learner-based approach

The effectiveness of students' performance within the field of higher education is significantly determined by learner autonomy. Fostering learner autonomy has received great interest from researches all around the world (Dam, 1995; Holec, 1980; Little, 1991). This issue is closely related to learner-centered methods (Benson, 2011). The methods interpret autonomous learners to possess the ability to control and take responsibility of their learning (Cotterall, 2000). Learners are viewed as active interpreters and processers of knowledge, which is based on their own interests and needs (Littlewood, 1996, Brown, 2006).
This interest in the learner's role has given rise to the concept of learner autonomy.

Consequently, this concept has received much attention in research and education (Esch, 2010; Mariani, 1997). In addition to the emergence of learnercentered approaches to teaching, the importance of learner autonomy is justified for various reasons (Dam, 1995). Scientists argue that autonomous learners are more efficient. They consider that being able to take responsibility for one's own learning implies intrinsic motivation, metacognitive skills, and awareness of the subject (Lewis \& Reinders, 2008). These issues are 
related to efficient learning, which is greatly affected by the development of different factors. One of them is the development of information technology in a competitive market. It has led to the fast exchange of information. Autonomous learning implies the critical evaluation of and reflection on information. Students should be able to process this information on their own, i.e. autonomously (Holec, 1980; Wallace, 1991) in a variety of circumstances, taking into account activities practicing ESP speaking skills.

The context for English for Specific Purposes (ESP) language acquisition via speaking skills is an attempt to highlight the peculiarities of teaching and learning ESP speaking. The specifics of ESP inevitably imply the consistent and complex use of speaking skills. The globalization of business practices with greater emphasis on communication and intrapersonal skills has profoundly influenced the use of ESP speaking. The most notable situations requiring communication skills are discussions, oral presentations, participation in meetings, negotiations, instructions, conversations on the phone, and other similar forms of communication.

Learner autonomy has been studied by many scholars and practitioners (Thanasoulas, 2000; Littlewood, 2007; Hamilton, 2013; Benson, 2008), although it has not been developed much in the field of teaching foreign languages, especially ESP. Its importance is widely recognized but it is difficult to grasp, especially the strategies, which can promote a promising change in the students' level of autonomy (Yang, 1998; Huang, 2006; Gremo \& Riley, 1995). The issue of assessing learner autonomy in learning foreign languages is also of great importance, though it has not been studied that widely.

The aim of the present study is to check the assumption that in teaching the English language, in particular developing ESP speaking skills, role-play strategies contribute to learner autonomy and help work out techniques for assessing learner autonomy. In this context, the article foregrounds autonomy as a complex phenomenon and highlights the importance of developing ESP speaking skills via role play. This is followed by an experimental study. The findings of this study can be used as a reference when reflecting on teaching practices that foster learner autonomy. Finally, the authors conclude with pedagogical implications relevant for teaching speaking skills.

\section{Literature Review}

Researches have approached learner autonomy from different perspectives. As a result, there exist various views on fostering learners' autonomy. While these points of view may differ from one another, they do share some underlying assumptions. Certain strategies and processes show that learner autonomy can be fostered in an institutional setting. They all view learner autonomy as a learner's innate capacities (Benson, 2001; Errey \& Schollaert, 2005; Esch, 2010). All of them describe the promotion of learner autonomy as the provision of circumstances and contexts for language learners that will make the learners more likely to take charge of all or part of their language learning program.

To clarify the theories on the promotion of learner autonomy, Benson (2011) promoted six different approaches to fostering learner autonomy: resourcebased, technology-based, learner-based, classroombased, curriculum-based, and teacher-based approaches. Resource-based and technology-based approaches refer mainly to out-of-class strategies. The four latter approaches consider the issue from within-a-classroom context. That is why they are essential to this study. Learner-based approaches, as Benson (2011) believes, show the relationship of learner training to learner development, the example of which is Ellis and Sinclair's ${ }^{1}$ approach. Classroombased approaches, as Benson (2011) sees them, aim to promote learner autonomy by incorporating learners in the decision-making processes. Curriculum-based approaches, according to Benson (2011), show that learner control is extended to the curricular level, an example of which is Cotterall's (2000) approach. Teacher-based approaches, in Benson's (2011) view, emphasize that learner autonomy takes into account teacher autonomy. Although Benson identified different approaches on the promotion of learner autonomy, the lines between approaches are not clear cut.

Theories on the promotion of learner autonomy in education environment are manifold. Littlewood (1996) offers a special framework for developing autonomy in and through foreign language teaching. The offered framework, according to Littlewood (1996), demonstrates that autonomy is a multidimensional capacity in two different ways. The first variant shows that autonomy consists of three domains: autonomy as communication (autonomy on a task level), as learning (autonomy on learning level), and personally (autonomy on a personal level). The second variant believes that autonomy in any of these three domains covers two obligatory components, namely, ability and willingness, which can further be subdivided into two components: ability into knowledge and skills, and willingness into motivation and confidence. Littlewood's ideas on learner autonomy imply that both willingness and ability are inherent to the majority of other theories.

Littlewood's ideas were then developed by Dam

1 Ellis, G., \& Sinclair, B. (1989). Learning to learn English: A course in learner training. Teacher's book. Cambridge, UK: Cambridge University Press. 
(2011). His approach is more practical and detailed. The framework offered by Dam (2011), is, in Benson's (2011) terms, a classroom-based approach to the development of learner autonomy. Dam (2011) pays special attention to the teacher's role in the development of learner autonomy. The teacher should have students take over the responsibility of learning, i.e. planning, carrying out the plans, and evaluating the outcome.

Dam (2011) highlights some important principles in the development of learner autonomy. The first principle is the fundamental notion of choice. According to Dam, having a choice enhances motivation, requires reflection which has a positive impact on his or her self-esteem, and scaffolds students to work for themselves. The second one is the need for clear guidelines to be established so that the learners feel secure enough. The third one is the shift from teacher-guided learning to self-guided learning. Dam believes that the teacher's concern should be to help students take an active role in the assessment process. According to Dam, involving the learners in reflection, evaluation, and assessment is important because it provides evidence of progress, enhances motivation, and heightens awareness of learning.

Dam's approach is primarily concerned with improving the abilities related to learner autonomy. It was enlarged by Lewis and Reinders (2008) who concentrated especially on improving the willingness to take responsibility for learning. For Lewis and Reinders (2008), the major obstacle in encouraging learner autonomy lies in a teacher-centered learning approach. According to Lewis and Reinders (2008), teachers and students should value activities related to autonomous learning, such as reflection on and the evaluation of progress as well as engaging higher thinking skills.

Whereas Dam (2011) and Lewis and Reinders (2008) concentrated on learning experiences, Cotterall (2000) approached promoting learner autonomy by taking into account a curriculum-based perspective. According to Cotterall (2000), the major challenge in fostering autonomy lies in the transfer of responsibility for decision making about learning from the teacher to the learners. To overcome this challenge, Cotterall (2000) introduced some principles that aim at promoting self-control over learning. These principles relate to learner goals, motivation, tasks, learner strategies, and reflection on learning.

Cotterall (2000) elaborates on these principles. Any language course that aims at promoting learner autonomy should reflect the learners' goals in their language acquisition, offer special tasks to contribute to learner strategy, and develop motivation and reflection. It is evident that taking everything into account, as Crabbe (1993) suggests, an emphasis should be put on the teacher's role in developing learner autonomy. Some researchers concentrated their work on the teacher and his or her role in learner autonomy. For example, Powell (1988) argues that, while students are usually blamed for being heavily dependent on the teacher in their learning, teachers rely on students in their teaching as well, thinking that it is their job to teach and pass on information. In contrast, Powell (1988) points out that the role of the teacher is crucial in creating an atmosphere of trust and confidence, in which learners can exercise their independent judgement and pursue their interests.

Many researches relate learner autonomy with enhanced motivation as Ellis and Sinclair ${ }^{2}$ do in their model. The relationship between the two seems quite obvious; by allowing students to set and act according to their own goals, they become intrinsically motivated to achieve their goals. This is the conclusion of Dickinson (1995), who states that there is a dynamic relationship between such concepts as intrinsic motivation and learner autonomy. However, the direction of the connection has caused some debate. Spratt, Humphreys, and Chan (2002), for example, found that motivation may play an inhibiting or enabling role in the realization of learner autonomy: the connection between motivation and autonomy seems to be bidirectional. Thus, as Spratt et al. (2002) suggest, when facing resistance and avoidance on the students' behalf, rather than immediately pushing those students towards autonomy, the teacher should promote intrinsic motivation and devote time to activities that show the usefulness of language learning.

The research followed the scientists' point of view who analyzed the problem of learner autonomy and considered choice, goals, motivation, metacognition, support, and emotional climate to be the most important issues in fostering autonomy. From these, choice and support were chosen to be analyzed in this study. The authors of the study aim at verifying the supposition that role play in teaching foreign languages is a strategy that incorporates choice and support and contributes to learner autonomy.

\section{Materials and Methods}

\section{Background of the Research}

When deciding on the methods to be used in the current study, the researches consider key issues in this study as "fit for purpose" (Reinders, 2010). The strategy selected for this study is role-play strategies.

\footnotetext{
2 Ibid.
} 
It was chosen for several reasons: it fits well within the theoretical perspective, it provides depth to the research, and it fills a gap in the literature in relation to learner autonomy within the language learning context (Hurd, 1998). The undertaken research recognizes the learner-centered approach to be closely related to fostering autonomy. It was found that several factors contribute to learner autonomy development, which include the role of the teacher, the role of feedback, learner independence, learner confidence in their study ability, experience, and approach to studying (Cotterall, 1995). In the terms of different approaches, the authors of the article are concerned with the idea of introducing some creative elements (role plays) into the process of studying English for specific purposes (ESP). Role-play strategies were chosen due to the fact that role play is one of the staples of English as a foreign language teaching. Role plays are used to allow students to practice speaking in a conversational situation, build confidence and fluency, assess progress, and put learning into action (Brown, 2008). Role-play strategies found their roots in Vygotsky's theory (Brown, 2008). It was stated that the development of language performance occurred during sociocultural interactions in the learning process. Regarding the importance of speaking skills for professional communication, the authors made students communicate within the context of their future profession. After years of teaching experience, the researchers could affirm in this study that students' creative abilities are an inherent part of ESP studies among the students with higher levels of motivation and the teacher's contributions. This research pursues the idea that taking part in role plays can promote students' autonomous learning, thus considering a role play to be a strategy that is very important ${ }^{3}$.

\section{Participants}

The participants of the study were second-year students of the National Research University Higher School of Economics taking an ESP English course. A total of 38 second-year students (15 male and 23 female, aged 17 or 18, not married) participated in the experiment. 20 participants ( 9 male, 11 female) were members of the experimental group (the first one) and 18 (6 male, 12 female) were in the control group (the second one).

\section{Materials}

To identify the students' starting level an "Objective Placement Test" and the IELTS speaking test were taken

\footnotetext{
Knowles, M. (1975). Self-directed learning: A guide for learners and teachers. New York, NY: Cambridge: The Adult Education Company.
}

by both groups. The core textbook used in the research with the experimental group was "English for Business Studies in Higher Education Studies". Different role plays are presented in this book. It was supplemented with business textbooks and manuals, for example, "Business Vocabulary in Practice" and "Business Benchmark" Upper-Intermediate. The control group was exposed to traditional English language textbooks on business. The authors developed a questionnaire that was focused on assessing autonomy progress from the beginning of the course to the end.

In general, the learning process requires control and assessment. However, there is no consensus regarding the question whether the assessment of learner autonomy is possible or not (Benson, 2010). It is very difficult to assess learner autonomy from an external perspective (Sinclair, 1989; Gardner \& Miller, 1999) but self-control and self-assessment of language learning competencies greatly contribute to the autonomous language learning process (Kleppin, 2005). Taking everything into account, the authors of the experiment developed the questionnaire to see how students can assess themselves. The students in both groups were exposed to the questionnaire (Appendix 1).

\section{Research Design and Procedure}

The research incorporated several steps. At the beginning and at the end of the course (pre/post-tests), both groups of students were assessed to identify their level of English language competence. They were given the Objective Placement Test, Variant 3, CUP \& FLTRP, 2010 (consisting of 60 multiple-choice questions divided into three sections Language Use (40 items), Reading (10 items), and Listening (10 items)) as well as the IELTS Speaking Tests 1,3 Cambridge IELTS 10 Student's Book (4 sections). The next step was designing a special English course for the second-year students. The aim of the teaching program for the experimental group was focused on promoting learner autonomy in formal foreign language teaching and evaluating it.

The designed course took into account two notions contributing to autonomy and covering all the other ideas that were taken into consideration. The first and the most important was choice, since it encompasses all aspects of learning and connects English studies with students' lives, e.g. using topics that are relevant to them. Choice causes inherent motivation that leads students to take responsibility of the learning process. The main advantage of choice is in its offering various task alternatives, from which students can take the one that suits them best. The students in the experimental group were offered the following tasks: choosing information from the resource they selected, building up target language lists that they consider vital for 
making up a role play, and discussing the ideas with the partners and commenting on them.

The second notion that emphasizes the special role of the teacher is support, which means that students are given opportunities to work on their weaknesses and they are also aided in discovering their strengths. The students are allowed to choose either to work individually or with a partner/in groups, for all of the activities types' tasks are specially designed, and they are also guided (if necessary) in finding the relevant resources.

1. Under the terms of the experiment from the beginning of the study the students in the first group are offered tasks with elements of role plays and the teacher's assistance. During the course of instruction, the exercises are fully developed into role plays with a range of tasks and roles. The role of the teacher at this stage comes down to giving advice if necessary or commenting and evaluating, while the teaching program for the control group provided traditional methods.

2. As previously mentioned, a special course was designed for the experimental group. The control group undertook a traditional training course. At the end of the course both groups, experimental and control, were given identical tasks preparing role play, where the teacher only gave the name of the activity and references for the sources.

The role play, "Choosing a business location" was chosen for the experiment. This role play is based on the speaking activity from "English for Business Studies in Higher Education Studies", the core textbook for the second-year students. The exercises from the book give information for researching the main types of business location criteria and lists of businesses with products and services. The aim of these exercises is to be able to explain where different businesses should be located. The students should speak fluently and coherently.

\section{Results}

As English has become an international and communicative language, a variety of educational aspects are related to its learning. Learner autonomy is considered to be a key element for communication and plays a vital role in English language learning. That is why the results of this research are very important as they will contribute to the fostering of learner autonomy in language studies. A strategy such as a role play in relation to the purposes of this research is used to encourage students to take charge of their own learning.

The experiment started with determining the level of English language competence in both groups. The results showed that the level was equal in both the experimental and control groups.

- The experimental group of 20 students achieved the results which are given in the table.

Table 1

The experimental group results

\begin{tabular}{|c|c|}
\hline Number of students & Score (60) \\
\hline 2 & $56-59$ \\
\hline 4 & $53-55$ \\
\hline 3 & $50-51$ \\
\hline 2 & $47-49$ \\
\hline 3 & 40 \\
\hline 1 & 38 \\
\hline 2 & $32-35$ \\
\hline 1 & 30 \\
\hline 2 & 27 \\
\hline
\end{tabular}

- The control group of 18 students (whose results were rather close to the first group) showed the results presented below.

Table 2

The control group results

\begin{tabular}{|c|c|}
\hline Number of students & Score $(60)$ \\
\hline 2 & $55-57$ \\
\hline 2 & $52-54$ \\
\hline 3 & 51 \\
\hline 3 & $47-50$ \\
\hline 3 & $40-45$ \\
\hline 1 & 37 \\
\hline 1 & 33 \\
\hline 1 & 29 \\
\hline 2 & $27-28$ \\
\hline
\end{tabular}

Both the experimental and the control groups were given the IELTS Speaking Test (IELTS Speaking Tests 1, Cambridge IELTS 10 Student's Book (4 sections) and evaluated according to the criteria given below ${ }^{4}$.

The students' evaluation from the speaking test is presented in the Table.

The pre-test showed that the level of English language competence and the level of speaking skills were practically equal in both groups. These tests were

4 IELTS Advantage. (2015). IELTS Speaking criteria. Retrieved from
https://www.ieltsadvantage.com/2015/06/28/ielts-speaking-criteria/ 
Table 3

IELTS Speaking Test criteria

\begin{tabular}{|c|c|c|c|}
\hline \multirow{2}{*}{ Aspect } & \multicolumn{3}{|c|}{ Criteria } \\
\hline & Fair & Good & Excellent \\
\hline Fluency and Coherence & $\begin{array}{l}\text { Is willing to speak at length, } \\
\text { though may lose coherence } \\
\text { at times due to occasional } \\
\text { repetition, self-correction and } \\
\text { hesitation. } \\
\text { Uses a range of connectives } \\
\text { and discourse markers but not } \\
\text { always appropriately. }\end{array}$ & $\begin{array}{l}\text { Speaks at length without } \\
\text { noticeable effort or loss of } \\
\text { coherence. } \\
\text { May demonstrate language- } \\
\text { related hesitation at times } \\
\text { and/or self-correction. } \\
\text { Uses a range of connectives } \\
\text { and discourse markers with } \\
\text { some flexibility. }\end{array}$ & $\begin{array}{l}\text { Speaks fluently with only } \\
\text { occasional repetition or self- } \\
\text { correction; hesitation is usually } \\
\text { content-related and only rarely } \\
\text { to search for language. } \\
\text { Develops topic coherently and } \\
\text { appropriately. }\end{array}$ \\
\hline Lexical Resource & $\begin{array}{l}\text { Has a wide enough vocabulary } \\
\text { to discuss topics at length and } \\
\text { make meaning clear in spite of } \\
\text { inappropriacies } \\
\text { Generally, paraphrases } \\
\text { successfully }\end{array}$ & $\begin{array}{l}\text { Uses vocabulary resource } \\
\text { flexibly to discuss a variety of } \\
\text { topics } \\
\text { Uses some less common and } \\
\text { idiomatic vocabulary } \\
\text { with some inappropriate } \\
\text { choices } \\
\text { Uses paraphrase effectively }\end{array}$ & $\begin{array}{l}\text { Uses a wide vocabulary resource } \\
\text { readily and flexibly to convey } \\
\text { precise meaning } \\
\text { Uses some less common and } \\
\text { idiomatic vocabulary skillfully } \\
\text { with occasional inaccuracies } \\
\text { Uses paraphrase effectively as } \\
\text { required }\end{array}$ \\
\hline Grammatical Range and Accuracy & $\begin{array}{l}\text { Uses a mix of simple and } \\
\text { complex structures, but with } \\
\text { limited flexibility } \\
\text { May make frequent mistakes } \\
\text { with complex structures, } \\
\text { though these rarely cause } \\
\text { comprehension problems }\end{array}$ & $\begin{array}{l}\text { Uses complex structures, with } \\
\text { some flexibility } \\
\text { Fluently produces error- } \\
\text { free sentences, though some } \\
\text { grammatical mistakes persist }\end{array}$ & $\begin{array}{l}\text { Uses a wide range of structures } \\
\text { flexibly } \\
\text { Produces a majority of error- } \\
\text { free sentences with only very } \\
\text { occasional inappropriacies or } \\
\text { basic/nonsystematic errors }\end{array}$ \\
\hline Pronunciation & $\begin{array}{l}\text { Uses a range of pronunciation } \\
\text { features with mixed control } \\
\text { Shows some effective use } \\
\text { of features, but this is not } \\
\text { sustained } \\
\text { Can generally be understood } \\
\text { throughout, though } \\
\text { mispronunciation of individual } \\
\text { words or sounds reduces clarity } \\
\text { at times }\end{array}$ & $\begin{array}{l}\text { Shows all the positive features } \\
\text { of the "fair" answer and some, } \\
\text { but not all of the positive } \\
\text { features of the "excellent" } \\
\text { answer }\end{array}$ & $\begin{array}{l}\text { Uses a range of pronunciation } \\
\text { features } \\
\text { Sustains flexible use of features } \\
\text { with only occasional lapses } \\
\text { Is easy to understand } \\
\text { throughout; the first language } \\
\text { accent has minimal effect on } \\
\text { intelligibility }\end{array}$ \\
\hline
\end{tabular}

Tbale 4

Speaking test evaluation

\begin{tabular}{lcc}
\hline & Experimental group (20) & Control group (18) \\
\hline Fair & 4 & 5 \\
Good & 10 & 10 \\
Excellent & 6 & 3 \\
\hline
\end{tabular}

carried out twice in pre- and post-learning activities.

As an activity aimed at preparing for the role play, the teacher for the experimental group introduced a topic and asked students to revise the "Skills Banks" from the core textbook for "reporting information to people'. He or she also provided with references to language materials on the topic (e.g. textbooks, "Business Vocabulary in Practice", "Business Benchmark" Upper-Intermediate). After receiving instructions, the students promptly started the activity. First, they distributed roles and reviewed the information, then they decided on the plot and the outcome. During the next stage, they utilized language materials to do exercises and select the target language, and forty minutes later they were ready to perform their role plays. One of the elements of the role play was "pyramid discussion", where at first the students discussed a suitable location in pairs; after a short while one pair joined another pair and soon this group of four came to an agreement on the issue and joined another group of four until they came up with a single decision.

In both groups, the teacher started the activity by explaining the gist of the key issue. The issue is why location is important for business. This issue was presented in both the experimental and control groups 
as a major idea at the beginning of the role play. After that, the control group began discussing information on the types of business location criteria, distributing the roles and doing language exercises as a whole class, under the teacher's supervision. Most of the time was devoted to determining the structure of the role play and its outcome, as the students could not come to one decision, interrupted each other, or sometimes did not have anything to suggest. It was evident that their discussions skills were underdeveloped. It took the control group an hour and fifteen minutes to get ready to conduct their role plays. It was evident that those students lacked skills in autonomous work and were dependent on the teacher's support and assistance.

The students in both groups were evaluated according to the role-play criteria given below. It should be noted that alongside with teacher's evaluation, peer assessment was conducted in the experimental group.

The students in the experimental group got "good" and "excellent" marks in terms of "content", "organization", and "scenario" aspects, while the students in the control group displayed "fair" and "good" results for the same aspects. This can be explained by the fact that the experimental group had been exposed to the role-play practice in the language classroom whenever it took place (at least twice a month).

The results given below show the final marks of the students from both groups.

At the end of the course, the students from both groups were assessed again to see the progress of their English language competence. They were given the Objective Placement Test, Variant 1 CUP \& FLTRP, 2010 (consisting of 60 multiple-choice questions divided into three sections Language Use (40 items), Reading (10 items), Listening (10 items)):

- The experimental group of 20 students achieved the results presented in the Table below.

- The control group of 18 students (whose results were rather close to the first group) achieved the results, shown in the Table.

Table 5

Role-play criteria

\begin{tabular}{|c|c|c|c|}
\hline \multirow{2}{*}{ Aspect } & \multicolumn{3}{|c|}{ Criteria } \\
\hline & Fair & Good & Excellent \\
\hline Content & $\begin{array}{l}\text { Role play was disjointed in } \\
\text { content at times, } \\
\text { topic covered }\end{array}$ & $\begin{array}{l}\text { Role play was slightly disjointed } \\
\text { in content, topic covered }\end{array}$ & $\begin{array}{l}\text { Role play was cohesive and } \\
\text { contained all the necessary } \\
\text { elements, fully covered topic }\end{array}$ \\
\hline \multirow[t]{2}{*}{ Organization } & $\begin{array}{l}\text { Presentation was only basically } \\
\text { organized. }\end{array}$ & $\begin{array}{l}\text { Presentation was fairly well } \\
\text { organized. }\end{array}$ & Presentation was well organized. \\
\hline & $\begin{array}{l}\text { The transitions between the } \\
\text { role plays and the narrator are } \\
\text { omitted sometimes and other } \\
\text { presentation components were } \\
\text { adequate. }\end{array}$ & $\begin{array}{l}\text { The transitions between the } \\
\text { role plays and the narrator and } \\
\text { other presentation components } \\
\text { flowed smoothly at times. }\end{array}$ & $\begin{array}{l}\text { The transitions between the role } \\
\text { plays and the narrator and other } \\
\text { presentation components flowed } \\
\text { smoothly. }\end{array}$ \\
\hline Scenario & $\begin{array}{l}\text { Scenario was not very realistic, } \\
\text { sometimes inappropriate for } \\
\text { class, or developed to some } \\
\text { extent. } \\
\text { Scenario tried to incorporate } \\
\text { course concepts. }\end{array}$ & $\begin{array}{l}\text { Scenario was realistic and class } \\
\text { appropriate, } \\
\text { Course concepts could be } \\
\text { identified. }\end{array}$ & $\begin{array}{l}\text { Scenario was fully realistic, class } \\
\text { appropriate, well developed. } \\
\text { Scenario clearly incorporated course } \\
\text { concepts. }\end{array}$ \\
\hline Fluency & $\begin{array}{l}\text { Some students showed great } \\
\text { difficulty in performing the role } \\
\text { play, but were able to complete } \\
\text { the task. }\end{array}$ & $\begin{array}{l}\text { Students were able to perform } \\
\text { the role play, sometimes with } \\
\text { little difficulty. }\end{array}$ & $\begin{array}{l}\text { Students were able to perform the } \\
\text { role play clearly with no difficulty. }\end{array}$ \\
\hline Language Use & $\begin{array}{l}\text { In some cases, speech } \\
\text { was awkward but quite } \\
\text { comprehensible to understand }\end{array}$ & $\begin{array}{l}\text { Speech was awkward at times } \\
\text { but always understandable with } \\
\text { the use of target language }\end{array}$ & $\begin{array}{l}\text { Speech was clear and } \\
\text { comprehensible at all times }\end{array}$ \\
\hline
\end{tabular}

Table 6

Role play assessment in the experimental and control groups

\begin{tabular}{lcc}
\hline & Experimental group & Control group \\
\hline Fair & 6 & 2 \\
Good & 10 & 7 \\
Excellent & 11 & 2 \\
\hline
\end{tabular}


Table 7

The experimental group results

\begin{tabular}{lc}
\hline Number of students & Score (60) \\
7 & $58-60$ \\
5 & $55-57$ \\
2 & $50-53$ \\
3 & $48-49$ \\
1 & 47 \\
1 & 44 \\
1 & 38 \\
\hline
\end{tabular}

Table 8

The control group results

\begin{tabular}{lc}
\hline Number of students & Score (60) \\
\hline 3 & $54-58$ \\
2 & 53 \\
3 & $50-52$ \\
4 & $47-48$ \\
4 & $40-45$ \\
1 & 37 \\
1 & 33 \\
\hline
\end{tabular}

The final test showed that the level of English language competence and speaking skills improved in both groups. But in the experimental group, the number of students who got high scores surpassed the number of students in the control group.

Both the experimental and the control groups were given the IELTS Speaking Test (IELTS Speaking Tests 2, Cambridge IELTS 10 Student's Book (4 sections) and evaluated according to the speaking criteria, which was given earlier.

The students' answers in the experimental group were mainly evaluated as "good" and "excellent" in all aspects except for the "lexical resource" aspect, while the students in the control group generally received "fair" marks in the "fluency and coherence" and "grammatical range and accuracy" aspects. The students' answers from the control group in the terms of "lexical resource" and "pronunciation" aspects were more "fair" than "good". This can also be explained by the fact that the experimental group students had the opportunity to improve their speaking skills through role-play activities.

Table 9

IELTS Speaking Test evaluation

\begin{tabular}{lcc}
\hline & Experimental group (20) & Control group (18) \\
\hline Fair & 2 & 6 \\
Good & 9 & 9 \\
Excellent & 9 & 3 \\
\hline
\end{tabular}

Self-control and self-assessment of language learning competences are key issues in the autonomous language learning process (Kleppin, 2005). The results of the experiment showed that students in the experimental group were more likely to set goals, analyse their needs, plan their learning, and assess their competencies on their own. The students in the control group preferred to do it with the help of either the teacher or their peers.

\section{Statistical Data Processing}

Data analysis was carried out on the basis of different students' results as shown by a number of tests. To find out the correlation among different factors, Pearson's coefficient "P" was used. The analysis took into account the correlations with $p$-value less than $0,05(p<0,05)$. Only the results where the probability was equal to or more than $95(p \leqslant 0,05)$ are discussed in the article.

\section{Discussion}

Inthecurrentstudy, learnerautonomyis viewed from Benson's (2011) and Dam's (2011) views of a learner's willingness and ability to take the responsibility to plan, implement, monitor, and evaluate his/her own learning. Two essential components are implied in this point of view: the learner's responsibility and the teacher's role in supporting the learners to develop autonomy. This research examines and discusses the findings of the current study with references to previous studies in the field.

As mentioned earlier, two groups of students took part in the experiment. Their levels of English language competencies were basically equal. This gave us the opportunity to compare the effects of

Table 10

Pre-test and Post-test correlation results

\begin{tabular}{|c|c|c|c|c|c|c|}
\hline & $\begin{array}{l}\text { Pre-test average } \\
(\max 60)\end{array}$ & Mean difference & P-value & $\begin{array}{l}\text { Post-test average } \\
(\max 60)\end{array}$ & $\begin{array}{c}\text { Mean } \\
\text { difference }\end{array}$ & P-value \\
\hline Experimental group & 45 & 1 & Less 0,05 & 53 & 1 & Less 0,05 \\
\hline Control group & 44 & 1 & Less 0,05 & 48 & 1 & Less 0,05 \\
\hline
\end{tabular}


role-play strategies and conventional strategies for learning English and fostering learner autonomy. The results indicated that the experimental group showed a significant advantage over the control group. This means that using role-play strategies in EFL classes is worthwhile and more effective for fostering learner autonomy and improving the learning process. This finding is consistent with the results of previous studies showing that role play is an effective strategy for enhancing student vocabulary (Toumpaniari et al., 2015). Learner autonomy incorporates such issues as self-control and self-assessment (Kleppin, 2005). They arouse reflection on and awareness of students' competencies and therefore contribute to promoting their autonomy. According to the results, the participants in the experimental group were more autonomous, showing more self-control and selfassessment than the participants in the control group. The atmosphere in which they worked was more pleasant and engaging than the traditional method. A more creative learning environment was developed, which is consistent with studies on creativity (Piaget, 1972; Vincent \& Shepherd, 1998)

When discussing the teacher's role in fostering learner autonomy, it is necessary to mention that the results of the research show that the main peculiarity of the teacher's task in the experimental group classroom is not only developing learner autonomy principles, but also underlining how to put the principles into practice. In terms of teaching, the principles imply a major change in the role of the teacher (Benson, 2001). Instead of merely passing on knowledge, the teacher provides task alternatives for the students because activities facilitating autonomous learning in the language classroom require active participation from each student. In the course of the research, the first group of students was subdivided into three mini groups. To start a role play, the teacher provides an article or two for the first mini group of students to analyze how relevant it is/they are to the topic of the prospective role play. The second group of students looks through the article to identify the main ideas to build the role play on, and the third mini group decides on the target language to be used. It is evident that pair and group work have led to developing language and learning skills and generally contribute to learner autonomy.

Another example of a task that contribute to autonomous learning is when the teacher prepares to make the requirements and guidelines clear for the students. But instead of presenting information like in the control group, he or she gives out cards with slides from the information on them. The students work in pairs, then in groups, to generate the requirements and tutorial guidelines for the course. After a brief study they create a presentation on what the course will be like.

The research reveals that in order to help students discover their strengths and weaknesses, the teacher should promote that peer reviews be written in the form of logbooks, portfolios, and posters. Students might then be able to come up with suitable strategies to overcome problematic issues. The process and progress of learning can give way to self-assessment and make the evaluation of learning easier for the students.

This process seems to be inefficient without the teacher's participation. The primary role of the teacher in the experimental group was to create an atmosphere of trust and confidence, which makes the learners feel free to share their independent judgements and pursue their interests. It is necessary to note that the teacher only acts as a guide by providing starting points without subsequently transporting everyone to a pre-determined destination.

It can be noted that choice and support were very important in encouraging students to ask for help and advice from the teacher or other students in the group. As a consequence, they rendered assistance to others when it was necessary. In other words, it created the emotional atmosphere in the language classroom environment where every student was appreciated and trusted by the teacher and peers, which is critical for promoting learner autonomy.

The experiment showed that learner autonomy can be built from awareness through involvement and intervention to creation where learners become researchers themselves. First learners are aware of the teachers' goals, then they are taught to identify tasks and strategies. Next, learners are involved in selecting their own goals, modifying and adapting them to the learning program. Learners should get experience making choices from a range of options. Overall, they should know how to create their own goals and objectives.

It is evident from the research that for developing learner autonomy in the language classroom, the task of the teacher is to stimulate pair and group work to be interactive and cooperative, which are vital for developing language and the necessary learning skills. Explaining carefully why working with peers is important can ensure the change towards learnercenteredness.

The teacher gives clear general guidelines for the activity, thus laying the groundwork for introducing and conducting the role play, at the same time letting students have a say in time allocation, choosing the topic, discussing group roles, working out strategies, and the outcome of role play. In some cases, the teacher can identify the results that the students should come to, but they are allowed to reconsider the initial prescriptions and come up with their own 
variants. After negotiating the information in pairs, then in groups, they are ready to report the results in the form of a role play.

It seems to be important not to start learner autonomy promotion too abruptly; learner autonomy can best be developed only through careful and gradual pedagogical intervention (Nunan, 1997). Furthermore, the teacher should gradually provide guidance and support in this process, so that students can feel secure, even if their abilities are still lacking. The following steps for promoting leaner autonomy are thus proposed:

- making the learners aware of the goals, content, and materials of teaching

- letting the learners intervene in goal-setting procedures

- creating their own goals and objectives

- applying classroom content creatively in the role play

\section{Conclusion}

The previous analysis achieved the main purpose of the present study, which was to investigate the effects of using role-play strategies in fostering learner autonomy in ESP speaking. The current study showed that learner autonomy is regarded as a learner's willingness and ability to take responsibility to plan, implement, monitor, and evaluate his/her learning. Moreover, to instill autonomy skills among students, teachers should provide an educative environment where students can cultivate their own self-regulative skills. In the present study, the researchers provided such environment in the form of role play during ESP speaking classes. The results of the research emphasized the fact that the role-play strategies are of great importance for promoting learner autonomy. The data collected during the experiment revealed the fact that a battery of tests and materials contributed to developing students' autonomy in their English language classes. Overall, it should be highlighted that to outline the contributions of role play to the process of fostering learner autonomy it is necessary to make learners aware of the goals and content of teaching, let them intervene in goal-setting procedures, and apply classroom content creatively in the role play. Such involvement on the part of the learner is encouraged in the present study by the use of a subjective needs assessment. The learners reflected on their learning experiences and evaluated the opportunities made available to them in class. In terms of assessment and evaluation, the study contributes to the development of autonomy as one of the goals of the research. Therefore, the emphasis is on training students in the fields of self-control and self-assessment. The notion of learner autonomy as the provision of circumstances and contexts relevant to the role plays is more likely when the learners take charge of the whole or part of learner language program. The findings of this study can be used as a reference when reflecting on teaching practices that promote learner autonomy. The research evokes some surpassing issues, including the role of motivation in fostering autonomy, but this requires further research.

\section{References}

Benson, P. (2001). Teaching and researching autonomy in language learning. London, UK: Longman.

Benson, P. (2008). Teachers' and learners' perspectives on autonomy. In T. E. Lamb \& H. Reinders (Eds.), Learner and teacher autonomy: Concept, realities and responses (pp. 15-32). Amsterdam, Holland: John Benjamins.

Brown, H. D. (2006). Principles of language learning and teaching ( $5^{\text {th }}$ ed.). London, UK: Pearson Education ESL.

Cotterall, S. (1995). Readiness for autonomy: Investigating learner beliefs. System, 23(2), 195205.

Cotterall, S. (2000). Promoting learner autonomy through the curriculum: Principles for designing language courses. English Language Teaching Journal, 54(2), 109-117.

Crabbe, D. (1993). Fostering autonomy from within the classroom: The teacher's responsibility. System, 21(4), 443-452.

Dam, L. (2011). Developing learner autonomy with school kids: Principles, practices, results. In D. Gardner (Eds.), Fostering autonomy in language learning (pp. 40-51). Gaziantep, Turkey: Zirve University.

Dickinson, L. (1995). Autonomy and motivation: A literature review. System, 23(2), 165-174.

Errey, L., \& Schollaert, R. (2005). Whose learning is it anyway? Developing learner autonomy through task-based language learning. London, UK: Coronet Books.

Esch, E. (2010). Promoting learner autonomy: Criteria for the selection of appropriate methods. In R. Pemberton, E. S. L. Li, W. W. F. Or \& H. D. Pierson (Eds.), Taking control: Autonomy in language learning (pp. 35-48). Hong Kong, China: Hong Kong University Press.

Gardner, D., \& Miller, L. (1999). Establishing selfaccess. From theory to practice. Cambridge, UK: Cambridge University Press.

Gremo, M.-J., \& Riley, P. (1995). Autonomy, self- 
direction and self-access in language teaching and learning: The history of an idea. System, 23(2), 151164.

Holec, H. (1980). Autonomy and foreign language learning. Strasbourg, Germany: Council of Europe.

Huang, J. (2006, December). Fostering learner autonomy within constraints: Negotiation and mediation in an atmosphere of collegiality. Prospect: An Australian Journal of TESOL, 21(3), 38-

57. Retrieved from http://www.ameprc.mq.edu.au/ docs/prospect_journal/volume_21_no_3/21_3 3 Łing.pdf

Hurd, S. (1998). Too carefully led or too carelessly left alone? Language Learning Journal, 17, 70-74.

Kleppin, K. (2005). Assessment and autonomy in language learning. Berlin, Germany: Springer.

Lewis, M., \& Reinders, H. (2008). Using student-centered methods with teacher-centered students. Ontario, Canada: Pippin Publishing.

Littlewood, W. (1996). Autonomy: An anatomy and a framework. System, 24(4), 427-435.

Mariani, L. (1997). Teacher support and teacher challenge in promoting learner autonomy. Perspectives, a Journal of TESOL, 23(2), 5-19.

Nunan, D. (1997). Designing and adapting materials to encourage learner autonomy. In P. Benson \& P. Voller (Eds.), Autonomy and independence in language learning (pp. 192-203). London, UK: Longman.

Nunan, D. (2001). Principles of communicative language teaching. Cambridge, UK: Cambridge University Press.

Piaget, J. (1972). Intellectual evolution from adolescence to adulthood. Human Development, 15, 1-12. doi:10.1159/000271225

Powell, J. (1988). Reducing teacher control. In D. Boud (Ed.), Developing student autonomy in learning (pp. 109-118). London, UK: Kogan Page.

Reinders, H. (2010). Towards a classroom pedagogy for learner autonomy: A framework of independent language learning skills. Australian Journal of Teacher Education, 35(5), 40-55.

Spratt, M., Humphreys, G., \& Chan, V. (2002). Autonomy and motivation: Which comes first? Language Teaching Research, 6(3), 245-256.

Thanasoulas, D. (2000). What is learner autonomy and how can it be fostered? The Internet TESL Journal, 6(11), 29-34.

Toumpaniari, K., Loyens, S., Mavilidi, M. F., \& Paas, F. (2015). Preschool children's foreign language vocabulary learning by embodying words through physical activity and gesturing. Educational Psychology Review, 27(3), 445-456. doi:10.1007/ s10648-015-9316-4

Vincent, A., \& Shepherd, J. (1998). Experiences in teaching middle East politics via Internet based role-play simulations. Journal of Interactive Media in Education, 98(11). doi:10.5334/1998-11

Walker, C., \& Harvey, P. (2008). English for business studies in higher education studies. Glasgow, UK: Garnet Publishing Ltd.

Wallace, M. (1991). Training foreign language teachers: A reflective approach. Cambridge, UK: Cambridge University Press.

Yang, N.-D. (1998). Exploring a new role for teachers: Promoting learner autonomy. System, 26, 127-135. 


\section{Appendix 1}

Self-Assessment Questionnaire

\begin{tabular}{|c|c|c|c|c|c|c|}
\hline \multirow[t]{3}{*}{ Critical thinking skills } & \multicolumn{6}{|c|}{ The level of autonomyin both groups } \\
\hline & \multicolumn{2}{|c|}{ With the help of a teacher } & \multicolumn{2}{|c|}{ Together with a classmate/within a group } & \multicolumn{2}{|c|}{ On my own } \\
\hline & $\begin{array}{l}\text { Experimental } \\
\text { Group (20) }\end{array}$ & $\begin{array}{l}\text { Control } \\
\text { group (18) }\end{array}$ & $\begin{array}{l}\text { Experimental } \\
\text { Group (20) }\end{array}$ & Control group (18) & $\begin{array}{l}\text { Experimental } \\
\text { Group (20) }\end{array}$ & $\begin{array}{l}\text { Control } \\
\text { group (18) }\end{array}$ \\
\hline Can you set goals? & 2 & 9 & 5 & 7 & 13 & 2 \\
\hline $\begin{array}{l}\text { Can you analyze your } \\
\text { own needs? }\end{array}$ & 1 & 12 & 7 & 2 & 12 & 4 \\
\hline $\begin{array}{l}\text { Can you plan your } \\
\text { learning? }\end{array}$ & 3 & 2 & 4 & 0 & 13 & 16 \\
\hline $\begin{array}{l}\text { Can you assess your } \\
\text { language competences? }\end{array}$ & 5 & 14 & 5 & 2 & 10 & 2 \\
\hline $\begin{array}{l}\text { Do you know what you } \\
\text { are to do when you are } \\
\text { working with this or } \\
\text { that task? }\end{array}$ & 1 & 5 & 1 & 8 & 18 & 5 \\
\hline $\begin{array}{l}\text { Do you know what } \\
\text { prevents you from } \\
\text { completing the task? }\end{array}$ & 3 & 13 & 2 & 0 & 15 & 5 \\
\hline $\begin{array}{l}\text { Do you reflect on } \\
\text { materials you have } \\
\text { used? }\end{array}$ & 2 & 18 & 0 & 0 & 18 & 0 \\
\hline
\end{tabular}

